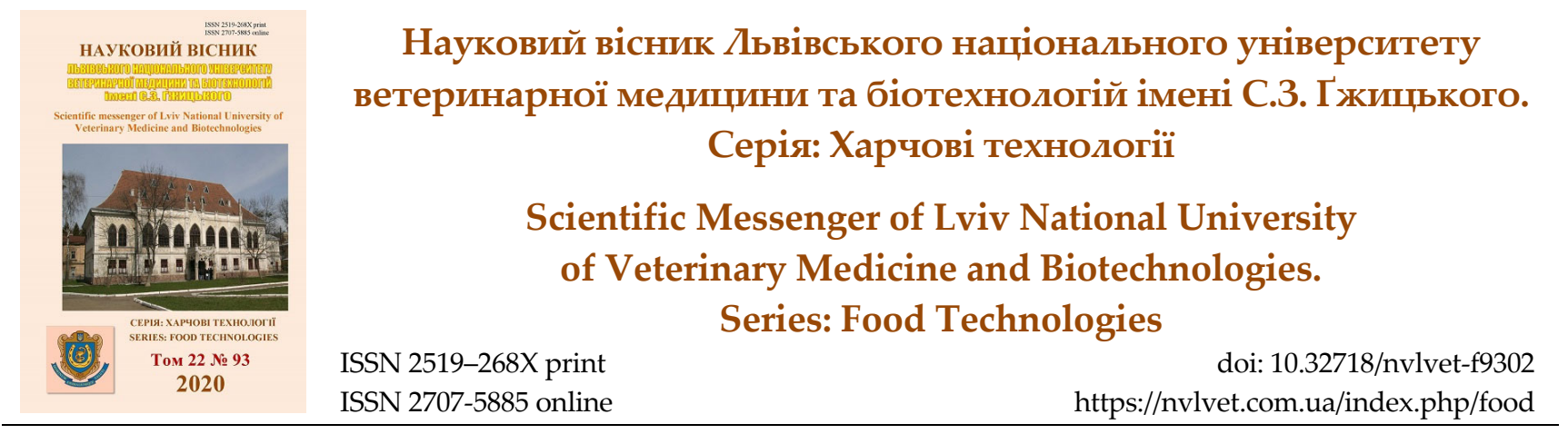

UDC 637.28:664.366:634.5.002.68

\title{
Spread technology with pine nuts meal development
}

\author{
V. O. Nagovska, N. B. Slyvka, Yu. R. Hachak, O. R. Mykhaylytska, O. Ya. Bilyk \\ Stepan Gzhytskyi National University of Veterinary Medicine and Biotechnologies Lviv, Ukraine
}

Article info

Received 22.01.2020

Received in revised form 24.02.2020

Accepted 25.02.2020

Stepan Gzhytskyi National University of Veterinary Medicine and Biotechnologies Lviv, ekarska Str., 50, Lviv,

79010, Ukraine.

Tel.: + 38-067-275-37-25

E-mail:slyvkanat@ukr.net
Nagovska, V. O., Slyvka, N. B., Hachak, Yu. R., Mykhaylytska, O. R., \& Bilyk, O. Ya. (2020). Spread technology with pine nuts meal development. Scientific Messenger of Lviv National University of Veterinary Medicine and Biotechnologies. Series: Food Technologies, 22(93), 9-14. doi: $10.32718 /$ nvlvet-f9302

The article describes the possibility of using vegetable raw materials such as pine nuts meal as a protein-vitamin complex in spread technology. Pine nuts are rich with essential amino acids, mono- and polyunsaturated fatty acids, polysaccharides and water-soluble sugars, fat-soluble and water-soluble vitamins, macro and trace elements. It has excellent stabilizing properties in emulsion systems. Also, in article is described technology of spreads made by transformation of a fat mixture. It is justified the choice of the parameters of individual technological operations, in particular, the pine nut meal adds to spread during the homogenization process. For this purpose, dry powder is mixed with pre-pasteurized water, butter or cream in a ratio of 1:2-1:10 at a temperature of $20-40{ }^{\circ} \mathrm{C}$. Mixture is kept at this temperature for 5-20 minutes. Then mixture is cooled to the spread homogenization temperature. Homogenization of the spread is carried out in order to improve the consistency and stability of taste during storage. Spread temperature during loading into the homogenizer should be $11-12{ }^{\circ} \mathrm{C}$ in summer and $14-15{ }^{\circ} \mathrm{C}$ in winter. Temperature of the spread after homogenization should be $13-15^{\circ} \mathrm{C}$. Optimal dose of cedar nuts meal is determined like $1 \%$ and $3 \%$ by weight of the finished spread. It is described organoleptic, physicochemical and structuralmechanical parameters of the finished product. Spreads containing $1 \%$ and $3 \%$ pine nuts have better heat resistance and moisture distribution. This can be explained by the fact that a small amount of pine nuts does not effects on the structure and texture of spreads. Researches of spread structural indicators have shown that the introduction of more than $3 \%$ of pine nuts has negative influence on it's structure, in fact, it causes poor moisture distribution and increases the speed of curing, which negatively effects on quality of the finished product. Using of pine nuts in the spread production is appropriate in terms of enrichment of the product with biologically active substances and in terms of expansion of the range of dairy products.

Key words: fat mixture, milk fat base, functional foods, oilseeds, pine nuts.

\section{Розроблення технології спреду із шротом кедрових горіхів}

\author{
В. О. Наговська, Н. Б. Сливка, Ю. Р. Гачак, О. Р. Михайлицька, О. Я. Білик
}

Львівський національний університет ветеринарної медицини та біотехнологій імені С. 3. Гжицького, м. Львів, Україна

У статті обтрунтовано можливість використання рослинної сировини, а саме шроту кедрових горіхів як білково-вітамінного комплексу в технологї спредів. Шрот кедрових горіхів багатий на незамінні амінокислоти, моно- та поліненасичені жирні кислоти, полісахариди і водорозчинні иукри, жиророзчинні та водорозчинні вітаміни, макро- і мікроелементи. Має відмінні стабілізуючі властивості в емульсійних системах. Розроблено технологію спредів, виготовлених способом перетворення жирової суміші. Сировина, яка використовувалась при проведенні досліджень, відповідала вимогам ДСТУ та інмої діючої в Україні нормативної документації. Обгрунтовано параметри окремих технологічних операцій, зокрема шрот кедрового горіха вносять під час гомогенізації спреду. Для иьього сухий порошок змішують із попередньо пастеризованою водою, маслянкою чи вериками у співвідношенні 1:21:10 при температурі 20-40 ${ }^{\circ}$. Далі суміш витримують при иій температурі протягом 5-20 хв. Після цзього суміш охолоджують до температури гомогенізації спреду. Гомогенізацію спреду проводять з метою покращення консистениії та стійкості смаку при зберіганні. Температура спреду при завантаженні у гомогенізатор має бути влітку $11-12{ }^{\circ} \mathrm{C}$, взимку - $14-15^{\circ} \mathrm{C}$. Температура спреду після гомогенізації повинна бути $13-15{ }^{\circ} \mathrm{C}$. Визначено оптимальну дозу шроту кедрових горіхів, щчо становить 1 i 3 \% від 
маси готового спреду. Описано органолептичні, фізико-хімічні та структурно-механічні показники готового продукту. Спреди із вмістом шроту кедрового горіха 1 \% і 3 \% мають кращі показники термостійкості та розприділення вологи. Це можна пояснити тим, що невелика кількість шроту кедрового горіха не впливає на структуру і консистенцію спредів. Дослідженнями структурних показників спредів встановлено, що при внесенні понад 3 \% шроту кедрових горіхів спостерігається погане розприділення вологи та збільшується швидкість затвердівання, шчо негативно позначається на якості готового продукту. Використання шроту кедрових горіхів у виробництві спредів є доцільним з огляду збагачення продукту біологічно активними речовинами та розщирення асортименту молочної продукиї.

Ключові слова: жирова суміш, молочно-жирова основа, функціональні продукти, насіння олійних культур, кедрові горіхи.

\section{Вступ}

На світовому ринку харчових продуктів в останні роки спостерігається тенденція до збільшення виробництва якісно нових, функціональних продуктів, які призначені для запобігання різних захворювань, зміцнення захисних сил організму, зниження ризику шкідливого впливу екологічних чинників, токсичних речовин (Simahina \& Naumenko, 2016; Nagovska et al., 2018; Slyvka et al., 2019). Такі продукти завдяки наявності в їх складі функціональних інгредієнтів (макроі мікроелементів, вітамінів, амінокислот, поліненасичених жирних кислот, антиоксидантів, фітостеролів та ін.) при систематичному вживанні впливають на метаболізм і фізіологічні функції організму людини (Poshadri et al., 2018). Функціональні продукти не $\epsilon$ лікарськими засобами, хоча і перешкоджають виникненню деяких захворювань та сприяють їх лікуванню (Sirohman \& Zavgorodnja, 2009).

Сучасний ринок функціональних продуктів на $65 \%$ складається із молочних. Вершкове масло та спреди є продуктами, що входять до щоденного раціону людини (Musiy et al., 2017). Одним із напрямів розвитку молочної галузі $є$ розробка нових масложирових продуктів, які мають лікувальнопрофілактичні, дієтичні та оздоровчі властивості (Musiy et al., 2017). Для їх виробництва використовують фруктово-ягідну, овочеву, дикорослу сировину, морські продукти та продукти бджільництва, кріопорошки тощо (Hachak et al., 2018). Тому виготовлення спредів 3 інноваційними компонентами 3 рослинної сировини, яка містить велику кількість біологічно активних речовин, має перспективне значення.

Для отримання високоякісного продукту при виробництві спредів необхідно правильно і раціонально підібрати всі рецептурні компоненти та провести відповідну механічну обробку, в тому числі гомогенізацію або диспергацію суміші.

Шрот кедрових горіхів - білково-вітамінний комплекс, збалансований самою природою. До його складу входять всі незамінні амінокислоти, необхідні для нормального обміну в організмі людини, у тому числі найбільш дефіцитні - лізин, метіонін і триптофан. Завдяки взаємному доповненню білків створюється сприятливе ферментативне середовище в організмі, яке налаштовує та коригує життєво-важливі функції організму, зміцнюючи і посилюючи процеси розвитку росту кісток і збільшення м'язової маси (Subbotina, 2005).

Вуглеводний склад шроту кедрового горіха представлений полісахаридами (крохмаль, клітковина, декстрини, пентозани) та водорозчинними цукрами (глюкоза, фруктоза, сахароза і рафіноза). У шроті виявлено високий вміст глюкози та незначну кількість фруктози і сахарози (Jaroshenko, 2013; ShidakovaKamenjuka et al., 2017).

Ліпіди ядра кедрового горіха представлені моно- i поліненасиченими жирними кислотами 3 оптимальним співвідношенням незамінних жирних кислот i токоферолів, надають продукту властивості регулятора ліпідного обміну і антиатеросклеротичну спрямованість дії (Henríquez et al., 2018).

Кедровий шрот містить у значній кількості всі жиророзчинні (провітамін А, E, D, K) і водорозчинні (група В, С, Р, РР) вітаміни, що дозволяє використовувати продукт для профілактики та корекції гіповітамінозів (O'Neil et al., 2015).

Шрот кедрових горіхів має багатий мінеральний склад, який відрізняється високим вмістом Калію, Магнію, Фосфору, Купруму, Цинку, Іоду. Біологічні форми Іоду, що містяться в ядрі кедрового горіха, сприятливо впливають на функцію щитоподібної залози і попереджають розвиток йододефіцитного стану (Babich et al., 2017).

Шрот кедрових горіхів завдяки хімічному складу нормалізує всі види обміну речовин; заповнює дефіцит вітамінів; має мембраностабілізуючий (Lutz et al., 2017), антитоксичний та імуномоделюючий (Lin et al., 2017) ефект. Крім цього, шрот також володіє антиоксидантною здатністю (Valero-Galván et al., 2019).

Особливості хімічного складу продуктів переробки кедрових горіхів зумовлюють проявлення ними відмінних стабілізуючих властивостей в емульсійних системах - у технології морозива, соусів та майонезів, сиркових продуктів та м'ясних напівфабрикатів (Dyshluk et al., 2018). Шрот кедрових горіхів широко застосовують для збагачення борошняних кондитерських виробів (Jaroshenko, 2013; ShidakovaKamenjuka, 2018). Також є дані про використання шроту насіння інших культур у харчовій промисловоcтi (Odarchenko et al., 2015; Izhevska, 2019).

Отже, комбінування молочно-жирової основи 3 шротом кедрових горіхів дозволить оптимізувати хімічний склад нових продуктів та підвищити у них вміст біологічно-активних речовин.

Метою роботи було розробити технологію спреду iз шротом кедрових горіхів та дослідити якісні показники продукту.

Для досягнення поставленої мети необхідно вирішити такі завдання:

- науково обгрунтувати можливість внесення та визначити оптимальні дози шроту кедрових горіхів;

- обгрунтувати особливості технології спредів із наповнювачами;

- дослідити комплекс показників якості готових продуктів. 


\section{Матеріал і методи досліджень}

Експериментальна частина роботи проведена на Самбірському сироробному заводі та в лабораторії кафедри технології молока i молочних продуктів Львівського національного університету ветеринарної медицини та біотехнологій імені С. З. Гжицького.

Спред - це харчовий жировий продукт (емульсія типу “вода в жирі"), який складається 3 молочного та рослинного жиру з масовою часткою загального жиру від $50 \%$ до $85 \%$ і в якому частка молочного жиру не менше $25 \%$ від вмісту загального жиру, із щільною або м'якою консистенцією з (без) додавання харчових добавок, наповнювачів та вітамінів.

Спред виготовляли способом перетворення жирової суміші.

Об'єктом наших досліджень було вибрано спреди із різним вмістом шроту кедрового горіха з метою збагачення спреду білковою складовою. Такий вибір зумовлений вимогами сучасного ринку молочної продукції України і намаганням створити нові продукти на молочній основі, в яких негативні властивості молочного жиру будуть нівельовані завдяки внесенню певної частки ненасичених жирних кислот, що містяться в рослинних жирах.

Було проведено дві серії досліджень.

У першій серії здійснювали вибір рослинних жирів, розробляли технологію спредів та їх рецептури і виготовляли спреди з різним вмістом шроту кедрового горіха, а саме: $1 \%, 3 \%, 5 \%$ та $7 \%$ від маси готового спреду.

У другій серії дослідів досліджували органолептичні, фізико-хімічні та структурно-механічні показники виготовлених спредів.

Контрольним зразком був спред із $20 \%$ заміною молочного жиру (ЗМЖ) без шроту кедрових горіхів. Як замінник молочного жиру використовували кондитерський жир “Олком" 3 масовою часткою трансізомерів олеїнової кислоти $3,6 \%$. До складу цього замінника жиру входить, крім інших рослинних жирів, оливкова олія, яка широко застосовується при виготовленні продуктів лікувально-профілактичного призначення.

Харчова цінність добавки "Шрот кедрового горіху" ПП "Мирослав" (Україна) у 100 г продукту: білки - 46 г, жири - 18 г, вуглеводи - 120 г. Калорійність добавки становить 425 ккал.

Досліджували органолептичні показники: смак, запах, колір, консистенція. Визначення фізикохімічних показників проводили згідно ГОСТ 5867 масову частку жиру, ГОСТ 3626 - масову частку вологи, ДСТУ 3976-2001 - пероксидне число, кислотність плазми.

Також встановлювали структурно-механічні властивості спреду: термостійкість, розподіл вологи, швидкість затвердіння.

Всі показники спредів 3 метою встановлення їх якості впродовж терміну реалізації визначали протягом 45 діб при температурі від 0 до $-5^{\circ} \mathrm{C}$.

\section{Результати та їх обговорення}

Шрот - твердий залишок насіння олійних культур після вилучення з нього олії екстракційним способом; побічний продукт виробництва рослинних олій, отриманий після екстрагування олій розчинниками. Внаслідок пресування насіння залишається макуха. Хоч більшість олії виділяється під час пресування, але в макусі іï̈ вміст усе ще становить до $10 \%$. Для остаточної екстракції олії з макухи використовують органічні розчинники, після обробки якими в насінні залишається лише 1,5-2\% олії. Шрот використовується перш за все як високопротеїнова добавка. Він багатий на рослинні білки, клітковину, вітаміни Е та В, Калій, Фосфор та інші мінеральні речовини (Cardoso et al., 2017).

У табл. 1 представлено рецептуру для спреду із $20 \%$ ЗМЖ та шротом кедрового горіха.

\section{Таблиця 1}

Рецептура спреду зі шротом кедрового горіха

\begin{tabular}{lcccc}
\hline \multicolumn{1}{c}{ Назва сировини } & \multicolumn{4}{c}{ Кількість шроту кедрового горіха, \% } \\
\cline { 2 - 5 } & $1 \%$ & $3 \%$ & $5 \%$ & $7 \%$ \\
\hline Високожирні вершки молочні, м.ч.ж. $72,5 \%$ & 799,92 & 799,92 & 799,92 & 799,92 \\
Замінник молочного жиру, м.ч.ж. $99 \%$ & 146,45 & 146,45 & 146,45 & 146,45 \\
Маслянка, м.ч.ж. 0,4 \% & 53,52 & 53,52 & 53,52 & 53,52 \\
Шрот кедрового горіха & 10 & 30 & 50 & 70 \\
Разом & 1010 & 1030 & 1050 & 1070 \\
\hline
\end{tabular}

При виробництві молочних продуктів важливим $є$ ïx органолептичні показники. Тому слід дослідити органолептичні характеристики отриманих спредів. У табл. 2 представлено характеристику зовнішнього вигляду, запаху та смаку, колір спредів із різною кількістю шроту кедрового горіха.

3 табл. 2 видно, що найбільш наближеними до контролю $є$ спреди із вмістом шроту кедрового горіха $1 \%$ i $3 \%$.

Дослідження фізико-хімічних показників нових видів спредів показало, що у всіх дослідних зразках масова частка жиру була $72,5 \%$, вологи - $25 \%$, СЗМЗ $-2,5 \%$, кислотність плазми - не вище $23{ }^{\circ} \mathrm{T}$. Ці показники відповідають діючій нормативній документації. Дослідні зразки спредів зі шротом кедрового горіха за вищевказаними показниками є повністю аналогічними спреду без шроту, що свідчить про правильність розробленої рецептури та вибраної технології.

Відомо, що термостійкість спредів є одним із найбільш важливих показників, що визначають їх консистенцію і структуру. У табл. 3 наведено структурі показники спредів. 
Таблиця 2

Органолептичні показники спредів зі шротом кедрового горіха

\begin{tabular}{|c|c|c|c|}
\hline \multirow{2}{*}{ Показники } & \multicolumn{3}{|c|}{ Кількість шроту кедрового горіха, \% } \\
\hline & 3 & 5 & 7 \\
\hline $\begin{array}{l}\text { Консистенція, } \\
\text { зовнішній } \\
\text { вигляд }\end{array}$ & $\begin{array}{ll}\text { Однорідна, м'яка, не } & \text { Однорідна, пластична, } \\
\text { дуже щільна і не дуже } & \text { щільна, з вкраплення- } \\
\text { пластична, 3 окремими } & \text { ми шроту кедрового } \\
\text { вкрапленнями шроту } & \text { горіха }\end{array}$ & $\begin{array}{l}\text { Однорідна, щільна, } \\
\text { ледь крихка, } 3 \text { вели- } \\
\text { кою кількістю вкрап- } \\
\text { лень шроту }\end{array}$ & $\begin{array}{l}\text { Дуже щільна, крихка, } \\
3 \text { яскраво вираженими } \\
\text { вкрапленнями шроту }\end{array}$ \\
\hline Смак і запах & $\begin{array}{l}\text { Чистий, вершковий, } 3 \text { присмаком пастеризації і } \\
\text { кедрового горіха }\end{array}$ & $\begin{array}{l}\text { Чистий, вершковий, } 3 \\
\text { вираженим смаком } \\
\text { кедрового горіха }\end{array}$ & $\begin{array}{l}\text { Яскраво виражений } \\
\text { смак кедрового горіха, } \\
\text { гіркуватий }\end{array}$ \\
\hline Колір & 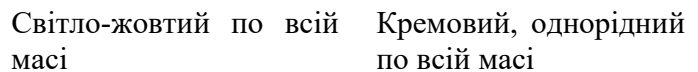 & $\begin{array}{l}\text { Світло-коричневий, } \\
\text { однорідний }\end{array}$ & $\begin{array}{l}\text { Коричневий по всій } \\
\text { масі }\end{array}$ \\
\hline
\end{tabular}

Таблиця 3

Структурні показники спредів

\begin{tabular}{|c|c|c|c|c|c|}
\hline \multirow[b]{2}{*}{ Назва показників } & \multirow{2}{*}{$\begin{array}{c}\text { Спред із } 20 \% \\
\text { ЗМЖ }\end{array}$} & \multicolumn{4}{|c|}{ Відсоток шроту кедрового горіха } \\
\hline & & $1 \%$ & $3 \%$ & $5 \%$ & $7 \%$ \\
\hline Термостійкість, Кт & 0,89 & 0,89 & 0,89 & 0,85 & 0,84 \\
\hline Розприділення вологи & Добре & Добре & Добре & Задовільно & Задовільно \\
\hline Швидкість затвердіння, с & $50-55$ & $50-55$ & $50-55$ & $60-65$ & $60-65$ \\
\hline
\end{tabular}

3 даних табл. 3 видно, що спреди із вмістом шроту кедрового горіха $1 \%$ і $3 \%$ мають кращі показники термостійкості та розприділення вологи. Це можна пояснити тим, що невелика кількість шроту кедрового горіха не впливає на структуру і консистенцію спредів. При збільшенні вмісту шроту до $5 \%$ та $7 \%$ розприділення вологи змінюється, тому що шрот зв'язує іiі певну кількість і таким чином волога розподіляється нерівномірно. Також наявність шроту кедрового горіха впливає на термостійкість і швидкість затвердіння спредів, що пов'язано, ймовірно, з наявністю у шроті ненасичених жирних кислот (Lutz \& Luna, 2016; Henríquez et al., 2018). Це призводить до зниження термостійкості та збільшення швидкості затвердіння спредів із вмістом 5 \% і 7 \% шроту.

Отже, виходячи із проведених досліджень, можна зробити висновок, що найбільш прийнятними до виробництва є спреди із вмістом шроту $1 \%$ та $3 \%$.

На рис. 1 представлено технологічну діаграму виробництва спреду із шротом кедрових горіхів.

Планується приймати на промислову переробку молоко, що відповідає вимогам ДСТУ 3662 “Молоко коров'яче незбиране” (DSTU 3662:2018, 2019). Залежно від якісних показників молоко сортують, визначають його кількість, очищають на сепараторахмолокоочищувачах. Для отримання вершків 3 м.ч.ж. 35 \% молоко направляють на сепарування. Отримані вершки накопичують у резервуарі для кисломолочних продуктів, попередньо охолодивши їх на пластинковому охолоджувачі. Знежирене молоко, отримане у процесі сепарування, пастеризують і накопичують у резервуарі для зберігання. Далі його підігрівають до температури $60-65^{\circ} \mathrm{C}$ і подають у ванну тривалої пастеризації. В цю ванну, яка має теплообмінну сорочку і помішувач, подають рослинний жир, повністю розплавлений i ретельно перемішаний. При цьому суміш знежиреного молока і рослинного жиру постійно перемішують. Потім отриману суміш емульгують в емульгаторі або шляхом циркуляції насосом до отримання однорідної маси при температурі 60-65 ${ }^{\circ} \mathrm{C}$. Після емульгування суміш охолоджують до температури $10-12{ }^{\circ} \mathrm{C}$ і направляють у резервуар, де знаходяться вершки.

Приймання та первинна обробка сировини<smiles>[Y]1CC1</smiles>

Сепарування молока при температура $45^{\circ} \mathrm{C}$, отримання вершків

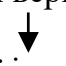

Приготування емульсії із рослинного жиру та знежиреного молока

Пастеризація та сепарування суміші вершків та емульсії, температура $85-90^{\circ} \mathrm{C}$

Отримання високожирних вершків

Нормалізація суміші високожирних вершків

$$
\downarrow
$$

Перетворення суміші високожирних вершків у

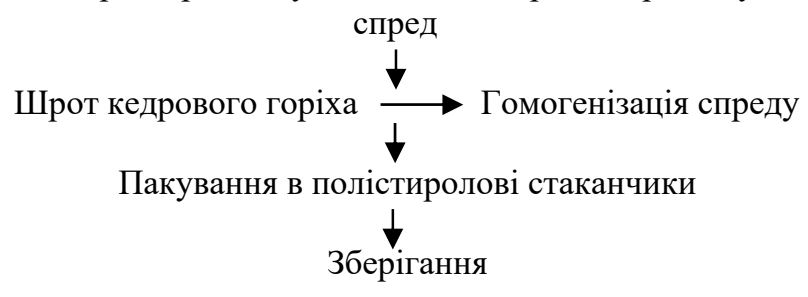

Рис. 1. Технологічна діаграма виробництва спреду із шротом кедрових горіхів

Суміш пастеризують при температурі 85-90 ㄷ. У випадках, коли смак суміші недостатньо виражений, а також при переробці вершків другого гатунку, температуру пастеризації підвищують до 92-95 ${ }^{\circ} \mathrm{C}$. Це сприяє аерації суміші та утворенню сульфгідрильних сполук, які разом з іншими речовинами надають 
спреду присмаку пастеризації та підвищують його стійкість при зберіганні.

Жирову суміш сепарують на сепараторах для високожирних вершків. Оптимальна температура сепарування становить $60-70^{\circ} \mathrm{C}$. Продуктивність сепаратора регулюють таким чином, щоб масова частка вологи у високожирних вершках була на 0,6-0,8 \% меншою, ніж необхідно у спреді, а масова частка жиру в маслянці не перевищувала 0,4 \%. Високожирні вершки при необхідності нормалізують за вмістом вологи та жиру. Для нормалізації високожирних вершків використовують маслянку, пастеризоване незбиране молоко, вершки або високожирні вершки з меншим вмістом жиру. Нормалізовані високожирні вершки з нормалізаційних ванн насосом подають у маслоутворювач. В маслоутворювачі одночасно швидке охолодження і механічна дія приводять до перетворення їх у спред.

При виробництві спреду до нього в процесі гомогенізації вносять шрот кедрового горіха у кількості 10 або 30 кг на 1000 кг готового продукту. Для цього сухий порошок змішують із попередньо пастеризованою водою, маслянкою чи вершками у співвідношенні 1:2-1:10 при температурі $20-40{ }^{\circ} \mathrm{C}$ та наступною витримкою при цій температурі протягом 5-20 хв. Підготовлений шрот охолоджують до температури гомогенізації спреду. Гомогенізацію спреду проводять $з$ метою покращення консистенції та стійкості смаку при зберіганні. Температура спреду при завантаженні у гомогенізатор має бути влітку $11-12^{\circ} \mathrm{C}$, взимку - $14-15^{\circ} \mathrm{C}$. Температура спреду після гомогенізації повинна бути $13-15^{\circ} \mathrm{C}$. Далі його фасують.

Готовий спред фасують у полістиролові коробочки, масою по 200 г і герметично закривають. Потім їх укладають у коробки або ящики з картону, паперу чи іншого матеріалу. Згідно діючих стандартів на пакування.

Зберігання і транспортування спредів здійснюється відповідно ДСТУ 4445:2005 “Спреди і суміші жирові. Загальні технічні умови”.

Продукти зберігають при відносній вологості повітря не більше ніж 75 \% і за таких температурних режимів:

$$
\begin{aligned}
& \text { - режим } 1-0--5{ }^{\circ} \mathrm{C}-45 \text { діб; } \\
& \text { - режим } 2--5--11{ }^{\circ} \mathrm{C}-75 \text { діб; } \\
& \text { - режим } 3--11--18{ }^{\circ} \mathrm{C}-90 \text { діб. }
\end{aligned}
$$

\section{Висновки}

На основі літературних даних та експериментальних досліджень вибрано як білково-вітамінний збагачувач шрот кедрових горіхів. Розроблено рецептуру i технологію нового спреду із вмістом шроту кедрових горіхів 1 та $3 \%$. Обгрунтовано параметри окремих технологічних операцій. Досліджено основні фізикохімічні показники готового продукту. Визначено структурні показники спредів та встановлено, що при внесенні більше $3 \%$ шроту кедрових горіхів спостерігається погане розприділення вологи та збільшується швидкість затвердівання, що негативно позначається на якості готового продукту.
Перспективи подальших досліджень. Отримані результати зумовили такі напрями подальших досліджень: дослідження жирнокислотного та амінокислотного складу готового продукту та проведення його промислової апробації.

\section{References}

Babich, O. O., Milent'eva, I. S., Ivanova, S. A., Pavsky, V. A., Kashirskikh, E. V., \& Yang, Y. (2017). The Potential of Pine Nut as a Component of Sport Nutrition. Foods and Raw Materials, 5(2), 170-177. doi: 10.21603/2308-4057-2017-2-170-177.

Cardoso, B. R., Duarte, G. B. S., Reis, B. Z., \& Cozzolino, S. M. F. (2017). Brazil nuts: Nutritional composition, health benefits and safety aspects. Food Research International, 100(2), 9-18. doi: 10.1016/j.foodres.2017.08.036.

DSTU 3662:2018 (2019). Moloko-syrovyna korov`iache. Tekhnichni umovy. Kyiv (in Ukrainian).

Dyshluk, L. S., Sukhikh, S. A., Ivanova, S. A., Smirnova, I. A., Subbotina, M. A., Pozdnyakova, A. V., Neverov, E. N., \& Garmashov, S. Yu. (2018). Prospects for using pine nut products in the dairy industry. Foods and Raw Materials, 6(2), 264-280. doi: 10.21603/2308-4057-2018-2-264-280.

Hachak, Y., Gutyj, B., Bilyk, O., Nagovska, V., \& Mykhaylytska, O. (2018). Effect of the cryopowder "Amaranth" on the technology of meolten cheese. Eastern-European Journal of Enterprise Technologies, 1, 11(91), 10-15. doi: 10.15587/1729-4061.2018.120879.

Henríquez, C., Loewe, V., Saavedra, J., Córdova, A., \& Lutz, M. (2018). Effect of the type of packaging on the oxidative stability of pine nuts (Pinus pinea L.) grown in Chile. Journal of Food, 16(1), 255-262. doi: 10.1080/19476337.2017.1391332.

Izhevska, O. (2019). Investigation of lipids of flax seed meal and the prospect of using it in meat dishes. Scientific Messenger of LNU of Veterinary Medicine and Biotechnologies. Series: Food Technologies, 21(91), 9-13. doi: 10.32718/nvlvet-f9102.

Lin, S., Liu, X., Liu, B., \& Yu, Y. (2017). Optimization of pine nut (Pinus koraiensis) meal protein peptides on immunocompetence in innate and adaptive immunity response aspects. Food and Agricultural Immunology, 28(1), 109-120. doi: 10.1080/09540105.2016.1228835.

Lutz, M., Álvarez, K., \& Loewe, V. (2017). Chemical composition of pine nut (Pinus pinea L.) grown in three geographical macrozones in Chile. Journal of Food, 15(2), 284-290. doi: 10.1080/19476337.2016.1250109.

Lutz, M., \& Luna, L. (2016). Nuts and Body Weigh - An Overview. Journal of Nutrition and Health Sciences, 3(1), 104. doi: 10.15744/2393-9060.3.104.

Musiy, L., Tsisaryk, O., Slyvka, I., Mykhaylytska, O., \& Gutyj, B. (2017). Research into probiotic properties of cultured butter during storing. Eastern-European Journal of Enterprise Technologies, 3, 11(87), 31-36. doi: 10.15587/1729-4061.2017.103539.

Musiy, L., Tsisaryk, O., Slyvka, I., Mykhaylytska, O., \& Gutyj, B. (2017). Study of keeping probiotic properties of cultured butter in storage. Eureka: Life Sciences, 2(8), 27-33. doi: 10.21303/2504-5695.2017.00318. 
Nagovska, V. O., Hachak, Yu. R., Bilyk, O. Ya., Gutyj, B. V., Slyvka, N. B., \& Mikhailytska, O. R. (2018). Influence of thistle grist on organoleptic, physicochemical and microbiological parameters of kefir. Scientific Messenger of Lviv National University of Veterinary Medicine and Biotechnologies, 20(85), 166-170. doi: 10.15421/nvlvet8530.

Odarchenko, A. M., M'jachykov, O. V., Gasaj, Je. L., \& Albatova, Ja. Ju. (2015). Novyj vyd spredu pidvyshhenoi' biologichnoi' cinnosti. Progresyvni tehnika ta tehnologii' harchovyh vyrobnyctv restorannogo gospodarstva i torgivli, 2, 40-49. http://nbuv.gov.ua/UJRN/Pt_2015_2_6 (in Ukrainian).

O'Neil, C. E., Nicklas, T. A., \& Fulgoni, V. L. (2015). Tree nut consumption is associated with better nutrient adequacy and diet quality in adults: National Health and Nutrition Examination Survey 2005-2010. Nutrients, 7(1), 595-607. doi: 10.3390/nu7010595.

Poshadri, A., Ramesh, P., Naik, S., \& Phanindra, P. (2018). Nutraceutical/Functional Foods and their Assessment in Foods. International Journal of Pure \& Applied Bioscience, 6(2), 948-958. doi: 10.18782/2320-7051.6490.

Simahina, G. O., \& Naumenko, N. V. (2016). Harchuvannja jak osnovnij chinnik zberezhennja stanu zdorov'ja naselennja. Problemy starenija i dolgoletija, 25(2), 204 214. http://nbuv.gov.ua/UJRN/PSD_2016_25_2_4 (in Ukrainian).

Sirohman, I. V., \& Zavgorodnja, V. M. (2009). Tovaroznavstvo harchovih produktiv funkcional'nogo priznachennja: navch. pos. Centr uchbovoï literaturi, Kyiv (in Ukrainian).
Shidakova-Kamenjuka, E., Novik, A., \& Bolhovitina, E. (2017). Analiz soderzhanija osnovnyh pishhevyh veshhestv $\mathrm{v}$ produktah pererabotki greckogo i kedrovogo oreha. Scientifis Letters of Academic of Michal Baludansky, 5(4), 121-124 (in Russian).

Shidakova-Kamenjuka, O. G., Novik, G. V., Rogova, A. L., \& Savenko, A. D. (2018). Progresivni tehnika ta tehnologiï harchovih virobnictv restorannogo gospodarstva i torgivli, 1, 268-280 (in Ukrainian).

Slyvka, N. B., Bilyk, O. Ya, Mikhailytska, O. R., \& Nagovska, V. O. (2019). Improvement of technology of curd products with succade from pumpkin. Scientific Messenger of Lviv National University of Veterinary Medicine and Biotechnologies. Series: Food Technologies, 21(92), 47-52. doi: 10.32718/nvlvet-f9209.

Subbotina, M. A. (2005). Biohimicheskij sostav i tehnologicheskie svojstva semjan sosny sibirskoj. Kemerovo (in Russian).

Valero-Galván, J., Reyna-González, M., Chico-Romero, P.A., Martínez-Ruiz, N. del R., Núñez-Gastélum, J.A., Monroy-Sosa, A., Ruiz-May, E. \& Fernández, R.G. (2019). Seed Characteristics and Nutritional Composition of Pine Nut from Five Populations of P. cembroides from the States of Hidalgo and Chihuahua, Mexico. Molecules, 24(11), 2057. doi: 10.3390/molecules24112057.

Jaroshenko, N. Ju. (2013). Docil'nist' vikoristannja kedrovogo shrotu v prjanichnih virobah. Sbornik. nauch. trudov SWorld "Perspektivnye innovacii $\mathrm{v}$ nauke, obrazovanii i v transporte". Tehnicheskie nauki. MARKOVA A.D., Ivanovo, 4(17), 26-29 (in Ukrainian). 